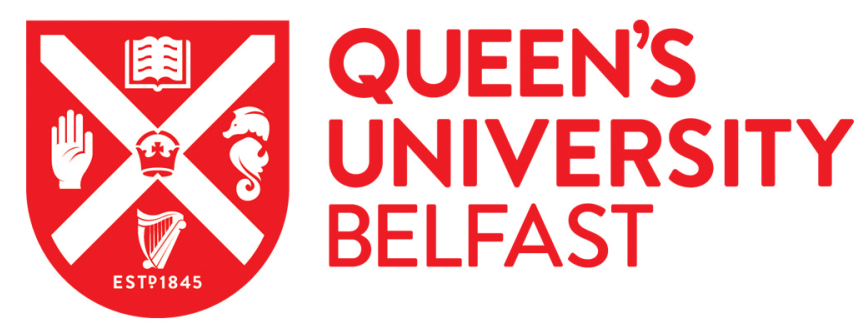

\title{
Beyond Muslim identity: Opinion-based groups in the Gezi Park protest
}

Baysu, G., \& Phalet, K. (2017). Beyond Muslim identity: Opinion-based groups in the Gezi Park protest. Group Processes \& Intergroup Relations, 20(3), 350-366. https://doi.org/10.1177/1368430216682353

\author{
Published in: \\ Group Processes \& Intergroup Relations
}

Document Version:

Publisher's PDF, also known as Version of record

Queen's University Belfast - Research Portal:

Link to publication record in Queen's University Belfast Research Portal

Publisher rights

() The Author(s) 2017. This work is made available online in accordance with the publisher's policies. Please refer to any applicable terms of use of the publisher.

\section{General rights}

Copyright for the publications made accessible via the Queen's University Belfast Research Portal is retained by the author(s) and / or other copyright owners and it is a condition of accessing these publications that users recognise and abide by the legal requirements associated with these rights.

Take down policy

The Research Portal is Queen's institutional repository that provides access to Queen's research output. Every effort has been made to ensure that content in the Research Portal does not infringe any person's rights, or applicable UK laws. If you discover content in the Research Portal that you believe breaches copyright or violates any law, please contact openaccess@qub.ac.uk. 
Running head: BEYOND MUSLIM IDENTITY: GROUPS IN THE GEZI PROTEST 1

Beyond Muslim identity:

Opinion-based groups in the Gezi Park protest

Gülseli Baysu \& Karen Phalet

\begin{abstract}
Author Note
Gülseli Baysu, Assoc. Prof., Psychology, Kadir Has University

Karen Phalet, Prof., Psychology, University of Leuven
\end{abstract}

Correspondence concerning this article should be addressed to Associate Prof. Gülseli Baysu, Department of Psychology, Kadir Has University. Address: Kadir Has Caddesi, Cibali, 34083, Istanbul, Turkey. Email: gulseli.baysu@khas.edu.tr, Tel: + 902125336532; Fax: + 902125336515

Research materials related to this paper can be requested by contacting the first author 
Running head: BEYOND MUSLIM IDENTITY: GROUPS IN THE GEZI PROTEST 2

Beyond Muslim identity: Opinion-based groups in the Gezi Park protest

\begin{abstract}
(149 words)
Media depicted Turkish Gezi Park protests as a clash between secularists and Islamists within a majority-Muslim country. Extending a social identity approach of protests, this study aims (1) to distinguish the protest participants in terms of their opinion-based group memberships, (2) investigate how their religious identification and their group membership were associated with democratic attitudes. 650 highly-educated urban young-adult participants were surveyed during the protest. Latent class analysis of participants' political concerns and online and offline actions yielded four distinct opinion-based groups labeled 'liberals', 'secularists', 'moderates' and 'conservatives'. Looking at the intersection of the participants' group identities with their Muslim identification, conservatives and moderates endorsed democratic attitudes less with increasing religious identification, whereas religious identification made little or no difference in liberals' and secularists' democratic attitudes. Our findings of distinct groups among protest participants in a majority-Muslim country challenges an essentialist understanding of religion as a homogeneous social identity.
\end{abstract}

Keywords: Opinion-based group, social identity, Muslim identification, protest, collective action, democratic attitudes, grievances, online activism 


\section{Beyond Muslim identity: Opinion-based groups in the Gezi Park protest}

The 2013 Gezi Park protests in Istanbul were sparked by the destruction of a city park to build a shopping mall. The protests quickly spread throughout Turkey and became news worldwide. International media depicted the protests as a clash between secularists and Islamists in a majority-Muslim country. Looking beyond a religious cleavage, the study aims (1) to delineate different groups of protest participants in terms of their opinion-based group identities and (2) to predict their democratic attitudes from the intersection of their religious identification with these group identities.

Our study builds on social identity research about the emergence of opinion-based identities (Bliuc, McGarty, Reynolds \& Muntele, 2007; McGarty, Bliuc, Thomas \& Bongiorno, 2009; Thomas, McGarty \& Mavor, 2009). This research shows that participants in action need not identify with pre-existing activist groups, yet opinion-based group memberships can emerge from a common stance on a specific issue (Bliuc et al., 2007; McGarty et al., 2009). Using this research as a heuristic framework, we propose that the Gezi park protest gave rise to plural opinion-based groups, who are aligned on selective issues or concerns, such as protecting the environment, women's rights, or laicité, through participants' engagement in specific actions. Our study derives different opinion-based groups bottom-up from participants' common concerns (why do they engage in the protest?) and their online and offline actions during the protest (how do they engage?) via latent class analysis.

Next we aim to explain participants' support for democracy from the intersection of their religious identification as Muslims with their opinion-based group memberships. Whereas religious identification is generally associated with less support for democratic attitudes such as freedom of speech (Inglehart \& Norris, 2003; Verkuyten \& Slooter, 2008), we argue that the political implications of the same religious identity depend on its intersection with different group identities (for intersectionality of gender and ethnicity, 
Deaux, 2001). Specifically, the association of Muslim identification with democratic attitudes should differ between distinct group identities. Democratic attitudes refer to support for democracy as a regime (Ariely \& Davidov, 2011), freedom of speech (Verkuyten \& Slooter, 2008), non-authoritarianism (Feldman, 2003), and positive attitudes towards minority groups (Verkuyten, 2007).

This study goes beyond previous research on collective action by studying the emergence and the multiplicity of opinion-based group identities inductively (beyond a single group identity or a dichotomy of supporters vs. non-supporters) and by covering both online and offline action forms (beyond a narrow focus on direct actions or intentions). Finally, this study de-constructs an essentialist representation of Muslim identity in Western media as a threat to democracy. Below we introduce the Gezi park protests and our theoretical framework.

\section{The Context of the Gezi Park Protests}

The Gezi park protests started on 26-May-2013 as a small peaceful protest in Istanbul against the destruction of Gezi Park. On 30 and 31 May several hundreds of protesters set up tents in the park (Bilgiç \& Kafkasl1, 2013). On May 30 at 5 am the police set fire to the tents. A few days later the protests escalated dramatically with 3.6 million people participating in $98 \%$ of Turkish cities. They lasted for about a month (for a detailed account, Postmes, Bezouw, \& Kutlaca, 2014).

Two surveys at the beginning of the protests of over 3000 participants each document the backgrounds, preferences and demands of early activists (Bilgiç \& Kafkasl1, 2013; Farro \& Demirhisar, 2014; KONDA, 2013). They were mostly educated young adults, as many women as men; $54 \%$ had not previously participated in any protest; and 70-80\% did not lean towards any political party (Bilgiç \& Kafkasl1, 2013; KONDA, 2013). The Gezi protests emulate contemporary mass protests like the Occupy movement (Milkman, 2014) as bottom- 
up social movements attracting a wide range of participants, voicing concerns about lifestyles, liberties and values, and reaching out to traditionally 'apolitical' youth (Farro \& Demirhisar, 2014; Gümüş \& Y1lmaz, 2015).

\section{Opinion-Based Group Identities}

Building on recent research about opinion-based group identities (Bliuc et al., 2007; McGarty et al., 2009; Thomas et al., 2009), the first aim was to delineate subgroups of protest participants with similar concerns and action forms. Social identity research explains collective action from activist identification (van Zomeren, Postmes, \& Spears, 2008) or ‘politicized collective identities' (Simon \& Klandermans, 2001). However, contemporary mass movements such as in Madrid, Cairo, New York or Istanbul attracted millions of people: a new generation of mostly urban and educated youth with no record of political activism or interest in conventional politics (Milkman, 2014). Rather than acting on prior politicized identities, participants in mass protests form opinion-based identities: "They simply share a common understanding and stance on a certain issue and hence come to share an opinionbased group membership" (McGarty et al., 2009, p.849). To map opinion-based group memberships during large-scale Gezi park protests, our online survey includes peripheral participants as well as hardcore activists.

We go beyond existing research on opinion-based groups in two ways. First, as contemporary mass protests connect various people, there should be plural opinion-based groups in a protest. Most research on opinion-based groups takes a binary approach: whether people support or oppose an opinion (government, Bliuc et al., 2007; a specific movement, Thomas, Mavor, \& McGarty, 2012; a militant group leader, Thomas et al., 2015). Yet, mass protests mobilize distinct groups with different stances on several issues. For instance, the Occupy Movement spilled over into multiple groups from anti-capitalists over environmentalists to LGBTQ and undocumented migrants (Milkman, 2014). 
Secondly, we examine configurations of different concerns with specific action forms to elucidate processes of selective alignment through joint participation in collective action. Research into opinion-based groups suggest that they form clear action norms, yet group identities are thought to precede the action (Thomas et al., 2009, 2012). Especially in mass protests, however, action may also create new group alignments (Drury \& Reicher, 2000; Reicher, 1996; Reicher, 2001). Thus, in-depth retrospective interviews with activists about their experiences during the Gezi protests revealed emergent identities around new alignments across different concerns (Acar \& Uluğ, 2016). As our study analyzes configurations of political concerns and actions during protests (no retrospective data), it does not imply a strict separation or directionality between concerns and actions.

\section{Political Concerns and Actions}

Political concerns_-grievances (Klandermans, 1997) or perceived injustice (Van Zomeren et al., 2008) — are well-documented triggers of collective action (van Stekelenburg \& Klandermans, 2013). Our study contextualizes concerns as perceived threats or violations of values such as life-style concerns motivating protest participation-in line with a 'value path' to political action (Inglehart \& Catterberg, 2002; van Stekelenburg \& Klandermans, 2013). Such value-based concerns better predict current political protests than instrumental concerns such as economic motives (van Stekelenburg Klandermans, \& van Dijk, 2009). In this study concerns cover general issues in collective action research such as democratic deficits, environmental problems, violations of women's or minority rights, and contextbound issues such as laicité vs. religious threat (rising Islamism) or national unity vs. ethnic threat (separatism) (Bilgiç \& Kafkasl1, 2013). Additionally, protest-based concerns'incidental disadvantage' (van Zomeren et al., 2008) or 'suddenly imposed grievances' (Walsh, 1981) — cover issues arising directly from the protest including police brutality and authoritarian government attitudes. 
We conceive of specific actions people take to express their concerns as a key performative dimension of their group memberships (Klein, Russell, \& Reicher, 2007; Reicher, 2001). "Collective action" is defined as action for a collective purpose on behalf of a group to improve its conditions (Wright, Taylor \& Moghaddam, 1990). Most collective action research focuses narrowly on attitudinal support or 'direct' actions (or intentions) like demonstrating or striking (van Zomeren et al., 2008). We broaden the scope from direct or street-level action to indirect actions such as hanging flags from windows, honking cars, switching lights on and off, or banging pots and pans. Indirect actions deserve attention as they are less costly than direct action, lowering the threshold for non-activists to join protests. They are increasingly popular in contemporary protests, as in the 2011 democracy protests in China where participants were holding jasmine flowers (Clemm, 2011).

We also asked about online activism. Social media are an effective action means to spread news (of meetings or emergencies) and to raise awareness about protests. While online protesting such as signing on-line petitions sometimes precludes offline protesting (Schuman \& Klein, 2015), online interaction can also set the scene for offline action; and it is an action means in itself (McGarty, Thomas, Lala, Smith \& Bliuc, 2014; Thomas et al., 2015). Due to the censored coverage of the Gezi park protests by traditional Turkish media, social media became all the more important. Most protesters (69\%) learnt about the protests via social media (KONDA, 2013). Therefore, online activism was an integral part of the political action repertoire in the Gezi park protests.

To conclude, rather than relying on pre-conceived identifications either with social categories (e.g., minority groups) or activist groups (e.g., feminist, trade unionist), we cover a broad range of political concerns and actions in the protests to inductively derive multiple opinion-based group memberships among protest participants. 
The second aim was to predict participants' democratic attitudes from the intersection of their religious identification with inductively-derived opinion-based identities (Deaux, 2001). In this way, we empirically question the reification of Muslim religious identity as antithetical to democratic citizenship in international media and public discourse. Most research on intersectionality refers to intersections of race and gender, showing that the same gender identity has different implications for different racial or ethnic groups (Deaux, 2001). Similarly, the same Muslim identity may carry different political meanings across different groups in the Gezi park protest. As the contents of specific opinion-based groups are not predefined, we have no specific hypotheses as to the nature of their interaction with religious identification.

Recent research in European migration contexts relating the religious identification of Muslim immigrant minorities to democratic political attitudes and engagement yields mixed findings (Fleischmann, Phalet \& Swyngedouw, 2013; Klandermans, Van der Toorn \& Van Stekelenburg, 2008; Simon \& Ruhs, 2008). As distinct from the Turkish context, the religious identity of Muslim citizens is a minority identity there, which sets them apart from the majority in their country of residence. To have a democratic political voice, this minority identity has to be seen as compatible with the national identity which includes the majority (Simon \& Ruhs, 2008).

Looking at the dynamic associations between religious identity and forms of democratic collective action or online activism, we underline the cultural constructions of these variables and their inter-relationships. Turkey is an interesting context because Muslim identity is a majority identity and internally diverse. Islam is more established and integrated into the political and societal culture. Consequently, people have different understandings of what being Muslim or Islam means (see Tessler, 2002 for the Arab world). This creates a strategic angle to de-amalgamate the Muslim identity of most participants in the Gezi park 
protests and to challenge a common representation of Islam and Muslim identity as a threat to democracy in Western media.

\section{Method}

\section{Participants}

During the first three weeks of the Gezi Park protests, 640 participants participated in an online survey (June 5-19, 2013). Mass protests began around May $31^{\text {st }}$-though gatherings in the park had begun a week earlier-and ended by June 2013. Our purposeful sample targeted anyone concerned about Gezi park protests including protesters and strong to weak supporters. Participants were reached through social media, e.g., via Facebook and Twitter (posting with trending hashtags). The effective sample consisted of highly-educated young adults (96\% university student/graduate, 75\% 17-30 years-old) from big cities (Istanbul 62\%, Ankara $11 \%$, İzmir $8 \%$, other cities $6 \%$, abroad $14 \%$ ), and slightly more women $(60 \%)$ than men. The sample covers a wide range of participants and supporters during Gezi park protests and its composition is similar to those reported in face-to-face surveys with larger samples (Bilgiç \& Kafkasl1, 2013; KONDA, 2013).

\section{Measures}

Political concerns. Concerns were mainly value-based (van Stekelenburg \& Klandermans, 2013) or protest-based (Walsh, 1981) with additional instrumental concerns, covering and supplementing common grievances in collective action research (van Stekelenburg \& Klandermans, 2013) with relevant context-specific concerns such as laicite. The specific contents of concerns were derived from early surveys of the Gezi park protests (Bilgiç \& Kafkasl1, 2013; KONDA, 2013). Fourteen reasons for supporting (or opposing) Gezi park protests were listed and people indicated to what extent they felt concerned on a five-point scale (not at all-very much). Value-based concerns $(n=9)$ referred to perceived threats or violations of values in various domains. Protest-based concerns $(n=3)$ were over 
authoritarianism, police brutality, and violent protesters. Instrumental concerns $(n=2)$ were over economy and foreign policy (for exact wordings of the concerns, Footnote $1^{1}$ ). Higher scores indicated more grievances.

Political action types. Attitudinal support was measured by two items with five-point scales: 'To what extent do you support the protests?' (not at all-totally supportive), and 'To what extent do you oppose the protests?' (totally opposed-not at all). Both items were averaged to indicate 'support', $r(639)=.87, p<.001, M=4.57, S D=0.93$.

Direct action ('To what extent did you participate actively in the protests and demonstrations by being there?') and indirect action ('Did you participate in any other ways to support the protest such honking your cars, banging pots and pans, turning on and off lights, putting Turkish flags etc.?') were measured separately with eight-point frequency scales $(1=$ none, $2=a$ few hours, $3=$ half a day, $4=1-2$ days, $5=3-4$ days, $6=5-6$ days, $7=7-8$ days, $8=$ more $)$. Direct action $(M=3.86, S D=2.25)$ and indirect action $(M=4.01, S D=2.59)$ were included as separate action forms, $r(641)=.38, p<.001$.

Social media usage was assessed for Facebook and Twitter by two items each: 'Approximately how much time per day did you use Facebook/Twitter to follow news and updates' or 'to share/post news and updates about the protests in Turkey', using seven-point frequency scales $(1=$ Never, $2=0-1$ hours, $3=1-3$ hours, $4=3-5$ hours, $5=5-7$ hours, $6=7-10$ hours, $7=$ more than 10 hours). Following and sharing items were highly correlated for Facebook $r(639)=.83, p<.001$ and for Twitter $r(621)=.84, p<.001$, hence averaged to construct two variables: Facebook use $(M=4.52, S D=1.83)$ and Twitter use $(M=3.97$, $S D=2.22), r(630)=.38, p<.001$.

Religious identification as Muslim was measured with one item (Postmes, Haslam \& Jans, 2013) on a seven-point scale (not at all-very strongly): 'To what extent do you identify as Muslim?'. 
Support for democracy was measured by four items (European Values Survey, 2008) with five-point scales (disagree-agree, $\alpha=.73$ ): 'Although it has some problems, democracy is better than other regimes', 'economy doesn't fare well in a democracy (R)', 'democracies are ridden with indecision, everybody has an opinion (R)' and 'democracies are not efficient in establishing public order (R)'.

Support for freedom of speech was measured by four items with five-point scales (disagree-agree, $\alpha=.77$ ): 'In public, we must be able to say what we think, even if we run the risk of offending religious people', 'In public, we must be able to criticize politicians, including the Prime Minister', 'In public, we must be able to criticize leading historical figures, including Atatürk ${ }^{2}$, 'It should always be possible to show illustrations which make fun of whichever religion on television and in newspapers'. They were adapted from surveys among Muslim immigrants in Europe (The Integration of European Second Generation Belgium, 2008).

Support for authoritarianism was measured by three items with five-point scales (disagree-agree, $\alpha=.71$ ) (Weber $\&$ Federico, 2007): e.g., 'In the era we live in, it is necessary to lead the country with an iron fist'.

Positive intergroup attitudes. The social distance question was used to measure positive attitudes towards minority groups (European Values Survey, 2008): 'Whom you would not like to have as a neighbor?'. Answers were dummy-coded: 1 =wouldnot want, 0 =doesnot matter. Religious minorities (Alevis, Christians, Jews, and Atheists), ethnic minorities (Kurds, Romans) and so-called marginalized minorities in the Turkish context (LGBTS, people who drink alcohol) were listed. These groups formed three factors, thus three distance scores from religious, ethnic and marginalized minorities were calculated (range 01). A lower score indicated more positive attitudes.

Table 1 shows descriptive statistics and correlations of the study variables. 
Control variables. Age was used as a control variable for democratic attitudes $(M=27.20, S D=7.04$, range $17-64$ years $)$. Gender and city were dropped from the analysis since they had no significant effects.

\section{Results}

Data analysis involved two parts. First a latent class analysis (LCA) was conducted using Mplus 7 (Muthén \& Muthén, 1998-2012). Similar to factor analysis assuming existence of latent dimensions, LCA assumes existence of latent groups of subjects and that respondents within the same group respond to items similarly (McCutcheon, 1987). Political concerns and action types were entered into the analysis to delineate different opinion-based group identities of the participants in the Gezi Park protests. Second, a series of regression analyses were conducted with these identities and Muslim identification and their statistical interactions as independent variables and democratic attitudes as dependent variables.

\section{Opinion-based group identities}

In deciding on the number of groups in LCA, we examined models with up-to-five latent classes, and selected a four-class model by comparing the interpretability and statistical soundness of different models (McCutcheon, 1987) (Table 2 for fit statistics). The four-class model compared to the three-class model gave better fit statistics (lower Bayesian Information Criterion [BIC] and Akaike Information Criterion [AIC] and higher entropy) and significantly improved the model fit over the three-class model using the bootstrap likelihood ratio test (BLRT) (Nylund, Asparouhov, \& Muthén, 2007). Comparing the four-class model to the five-class model, although the BLRT suggested significant improvement, other model fit indices showed little — if any_-improvement in terms of log-likelihood, AIC or BIC values (Figures in the Supplementary Material); and the four-class model had higher entropy. We concluded that the four-class model was the best fit for our data. 
The four different profiles of participants were labeled as 'liberal' (20\%), 'secularist' (42.3\%), 'moderate' (28.4\%) and 'conservative' (9.3\%) identities ${ }^{3}$. The choice of these labels was driven by the contents of distinctive concerns and actions of each group. These identities can be briefly defined as follows: "Liberals" are those who defend liberties for everyone, including the LGBT and ethnic minorities; 'Secularists' are those concerned with national unity and laicite, moderates were labeled as such because their concerns and actions showed selective overlap with liberals, secularists and conservatives; and conservatives were those pro-conservative government. Figure 1 displays the sum of probabilities of agreeing and strongly agreeing ${ }^{4}$ to various concerns by different groups. Figure 2 shows the mean frequencies of engagement in protests for each action type for different groups. We discuss below the concerns and action types that differentiate or overlap between different groups.

Protest-based concerns (i.e., authoritarian attitudes of the government, police violence and provocateurs) were the only concerns shared by all participants. Participants differed meaningfully, however, in their value-based concerns and to some extent in their action forms during the protests.

Both liberals and secularists shared similar value-based concerns about threats to the environment, democracy, and women's rights (Figure 1). Liberals and secularists also differed: Distinctive concerns for liberals were about the protection of minority rights, those for secularists were about perceived ethnic (separatist) and religious (Islamist) threats to the nation state, valuing national unity and principled laicité. As for actions, both liberals and secularists supported the protests, participated actively and used social media, though secularists preferred the indirect action slightly more than liberals who preferred the direct action (Figure 2).

Moderates showed some overlap with both liberals and secularists on value-based concerns such as threats to the environment, democracy and women's rights. Conservatives 
showed little overlap with others on value-based concerns. Typical concerns for conservatives referred to police violence, violent protesters and, to some extent, the authoritarian government response. Conservatives were also least willing to support the protests - with moderates occupying a middle-ground between secularists vs. conservatives. As for actions, protest engagement was limited to social media use for conservatives, whereas moderates combined social media with indirect action.

While this comparison across profiles is qualitative, as is generally the case for LCA, we can compare the four groups' overall latent class means statistically. Mplus 7 provides the latent mean differences from the largest class as the reference category, i.e., the secularists. The mean difference from secularists was -1.515 for conservatives $(p<.001),-0.401$ for moderates $(p=.046)$, and -0.755 for liberals $(p<.001)^{5}$

Looking at the importance of predictors (i.e., concerns and action) is also qualitative in LCA: those concerns and actions that differentiate across the latent classes are considered relatively better predictors. Endorsed by each group, protest-based concerns did not differentiate well across the four-latent classes. Instrumental concerns over economy and foreign policy did not differentiate well either, as they were not endorsed much by anyone. Actions, particularly social media, did not differentiate secularists, liberals and moderates. Results of an additional cluster analysis which provides quantitative information on the importance of the concerns and actions support our conclusions and shown in the Supplementary Material.

Finally, since concerns and actions were analyzed together to delineate the group identities, the association between identities and actions cannot be tested statistically. We conducted additional LCA using only concerns to delineate the identities (with very similar compositions to LCA solution here) and additional regression analyses using those latent classes as predictors and action forms as the dependent variables. Results supported our 
qualitative discussion of identities and action forms and are shown in the Supplementary Material.

\section{Associations of Muslim identification and opinion-based group identities with democratic attitudes}

Separate regression analyses were conducted with support for democracy, freedom of speech, authoritarianism and intergroup attitudes as dependent variables. For intergroup attitudes, the dependent variable was defined as a latent variable with distance towards religious, ethnic and marginalized minorities. As the predictor, the four groups were recoded as three contrasts using orthogonal contrast coding (Field, 2015): First contrast compared liberals and secularists to moderates and conservatives (coded as $22-2-2$ ); second contrast compared liberals and secularists (coded as 1 vs. -1 with the remaining two coded as 0 ), and third contrast compared moderates and conservatives (coded as 1 vs. -1 , with the remaining two coded as 0 ) (Table 1 for correlations). Orthogonal contrast coding was preferred because of the distinctions and similarities of concern and action profiles of liberals and secularists vs. moderates and conservatives and because of the absence of a single reference category as in the dummy-coding (Field, 2015). Additional analysis using linear trend coding of identities from liberal, secularist, moderates to conservatives shows very similar results to contrastcoding and can be seen in the Supplementary Material.

Three contrasts, Muslim identification (centered) and their statistical interactions were treated as independent variables and age as a control variable. The interactions and age were included in the analysis only when they were significant. Four self-identified Christians were excluded from the analysis. Results of the regression analyses were shown in Table 3.

First, participants were asked whether democracy was a desirable regime. Contrast 1 had a significant effect showing that liberals and secularists supported democracy more than moderates and conservatives. The intercept was above the midpoint of the scale, however, 
indicating that participants overall supported democracy as a regime. Neither Muslim identification nor the interaction had significant effects.

For endorsement of freedom of speech, all the contrasts had significant relationships showing that the difference between liberals and secularists (Contrast 2), that between moderates and conservatives (Contrast 3), and that between the first two and the last two (Contrast 1) were significant. Identification as Muslim was negatively related to freedom of speech. This relationship was qualified by a two-way interaction between contrast 1 and Muslim identification $(p=.012)$ as shown in Figure 3. A simple slope analysis (Preacher, Curran, \& Bauer, 2006) showed that the negative slope of Muslim identification was significant for both liberals and secularists $(t=-3.611, p=0.001, \mathrm{~d}=.29)$ and for moderates and conservatives $(t=-5.216, p<.001, \mathrm{~d}=.43)$, while the latter was stronger.

For authoritarianism, all the contrasts were significant showing that authoritarianism was endorsed by liberals less than secularists (Contrast 2), moderates less than conservatives (Contrast 3), and the first two less than the last two (Contrast 1). Muslim identification was positively related to authoritarianism. These effects were qualified by a two-way interaction between Contrast 1 and Muslim identification $(p=.021)$ as seen in Figure 4. Simple slope analysis showed that the slope of Muslim identification was significant for moderates and conservatives $(t=3.10, p=.002, d=.25)$, but not for liberals and secularists $(\mathrm{p}>.05)$.

For the social distance measure, Contrasts 1 and 2 were significant showing that liberals were less distant to minorities than the secularists (Contrast 2) and these two were less distant than moderates and conservatives (Contrast 1). Higher Muslim identification was related to higher distance. There were two significant two-way interactions of Contrasts 1 and 3 with Muslim identification (respectively, $p=.002, p=.008$ ). For the Contrast 1 interaction, the slope of Muslim identification was significant for liberals and secularists $(t=2.520, p=$ $0.012, d=.21)$ and moderates and conservatives $(t=5.309, p<.001, d=.44)$, while latter effect 
was much stronger (Figure 5). For the contrast 3 interaction, the slope of Muslim identification was significant for conservatives $(t=4.156, p<.001, d=.34)$ but not for moderates $(p>.05)$.

\section{Discussion}

This research aimed (1) to delineate different groups of protest participants in terms of their opinion-based group identities and (2) to predict their democratic attitudes from the intersection of their religious identification with these group identities. The focus was on the 2013 Gezi Park protests in Turkey, which was depicted as a divide between secularist and Islamists in a majority-Muslim country. Looking beyond this divide, our research challenges a homogenous representation of Muslim identity and its alleged association with undemocratic attitudes. First, participants' political concerns and actions were clustered in four groups which we labeled 'liberals', 'secularists', 'moderates' and 'conservatives'. Next these groups moderated the association of Muslim identification with democratic attitudes. Whereas conservatives and moderates endorsed democratic attitudes less with increasing religious identification, religious identification made little or no difference in liberals' and secularists' democratic attitudes.

Let us discuss the four group identities. Extending a social identity approach of collective action, these group memberships were conceptualized as opinion-based group memberships around shared political concerns and actions. Research into opinion-based groups (including the normative alignment model and the encapsulated model of social identity in action) suggest that people who share common grievances may share an opinionbased group membership with clear norms of action (Thomas et al., 2009, 2012). During mass protests, simultaneous processes of alignment and de-alignment of various concerns and actions among protest participants may give rise to different identities (Snow, Rochford, Worden \& Benford, 1986). The notion of alignment around shared concerns receives also 
indirect support from research on inductive social identity formation around shared goals or values through social interaction in small groups (Postmes, Haslam, \& Swaab, 2005). In this study we researched the political concerns while the protest was happening, rendering the directionality test from concerns to actions (or vice versa) less relevant, and we aimed to derive constellations of political concerns and actions to show group alignments. This study contributes to this research line by highlighting multiplicity: Multiple concerns and action forms allow for the expression of multiple group memberships beyond the focus on a single group or a dichotomy of supporters vs. non-supporters.

'Liberals' and 'secularists' shared concerns over environment, democracy and women's rights but also differed in their concerns over minority rights vs. religious and ethnic threat. While liberals took to the streets, secularists preferred indirect action. Indirect action forms such as banging pots and pans are in the repertoire of secularist action means in Turkey to communicate concerns over laicite. This finding resonates with the normative alignment model's argument that opinion-based groups have clear action norms (Thomas et al., 2009, 2012) and with Reicher's (2001) proposition that action types adopted by people document the performative nature of their group identities (Klein et al., 2007). The so-called 'moderates' could be considered as conservative secularists because their concerns and actions showed selective overlap with secularists and conservatives. Finally, conservatives' concerns were narrowly protest-based and their engagement was limited to online activism. A qualitative study of conservatives in the Gezi park protests supported our findings (Çelik, 2015).

Our findings go beyond the Gezi park protests and suggest new bottom-up methods to empirically investigate collective groups in contemporary mass protests across different cultural contexts. Latent class analysis allows for deriving multiple group memberships from the contents of shared political concerns and action forms. As a drawback of this approach, 
however, we couldnot measure self-identifications with these groups which could exist with or without self-identifications. Another issue is the difficulty in naming the groups. In Turkish, we use ‘özgürlükçü’ (literally, person defending liberties) to refer to liberals while in English, the word 'liberal' may refer to those following liberal philosophy. Similarly, we do not claim that 'moderates' indicate a group identity by itself but it is an empirically and theoretically distinguishable group from conservatives and secularists.

As for the main triggers of Gezi park protests, the value-based concerns such as threats to environment, democracy and women's rights, the so-called life style concerns, played a big role, in line with studies underlining their importance over instrumental concerns for contemporary protests (Inglehart ve Catterberg, 2002; Milkman, 2014; van Stekelenburg et al. 2009). Protest-based concerns (van Zomeren et al., 2009; Walsh, 1981)-highlighting the mutual interaction between (violent) protesters vs. the government and the police-also played a key role (Reicher, 1996). Qualitative studies of the Gezi park protests document the value- and protest-based grievances - ranging from democracy, minority rights to police brutality_as the main triggers of the protests (Acar \& Uluğ, 2016; Çelik, 2015; Farro \& Demirhisar, 2014; Gümüş \& Y1lmaz, 2015).

Both online and offline activism were common grounds for action, though somewhat differently for different groups. Research does not specify when online activism hinders or facilitates offline activism. One may presume that where traditional media censorship is prevalent, online activism becomes an essential action means. McGarty and colleagues (2014) showed how important social media activism was in the Arab spring. A study on the use of Tweeter during Gezi park protests showed how online and offline protesting was intertwined by analyzing the time series of the tweets with the major on-the-ground events throughout a month (Varol, Ferrara, Ogan, Menczer \& Flammini, 2014). Future research on both forms of action should consider the context of activism. 
The second objective was to investigate how participants' Muslim identification and their opinion-based group identities were associated with their endorsement of democratic attitudes. Based on the notion of intersectionality (Deaux, 2001), we expected that the association between Muslim identification and democratic attitudes would depend on these group memberships. While the Western interest in Muslims' democratic attitudes is increasing, our study provides a strategic angle to this question as Muslim identity is a majority identity and more diverse in Turkey. Thus we raise the question how identities and their corresponding relations to democratic attitudes and forms of collective action are constructed in the culture they are embedded in.

The fact that acceptance of democracy as a regime was consensual regardless of religious identification resonates with cross-national surveys which failed to find significant differences between Muslims and non-Muslims in their support for democracy (Inglehart \& Norris, 2003). Research comparing Middle Eastern Muslim countries (Jamal \& Tessler, 2008; Tessler, 2002) shows that Islamic attachments do not discourage support for democracy. However, comparing democratic attitudes such as freedom of speech and acceptance of minorities, Muslims were found to be less democratic than non-Muslims (Inglehart \& Norris, 2003; Verkuyten \& Slooter, 2008).

Going beyond this research, we showed that a common Muslim identity did not have the same political implications for democratic attitudes such as support for freedom of speech, anti-authoritarian attitudes and positive attitudes towards minorities, depending on the different political stances of protest participants. For liberals and secularists, it did not matter much whether they were strongly or weakly Muslim-identified, they endorsed the democratic attitudes nonetheless. For conservatives and moderates, however, increasing religious identification meant being less supportive of democratic attitudes. 
A following question is cross-cultural implications of these findings. Looking at Muslim immigrants in Europe, how would the dynamic relationship between their Muslim identity and democratic engagement unfold? Research across different European countries shows that the ways Muslim identities of immigrants are related to their civic identities and democratic engagement depend on the socio-political context (Fleischmann \& Phalet, 2016; Fleischmann et al., 2013). This relationship may also vary according to Muslims'own political stances on certain issues, or their opinion-based group identities. For instance, future research can investigate the ethnic vs. civic political concerns of Muslim immigrants (e.g., their positions over a homeland crisis vs. discrimination in the society they live) and how these would interact with their Muslim identification to predict when and how they would engage in collective action.

Another question is whether we can talk about the intersectionality of Muslim identity in the so-called "democracy watch" protests in Turkey against the military coup attempt of 2016 (Unver \& Alassaad, 2016). Research by KONDA (2016) showed that most protesters were pro-conservative government; they identified their life styles as conservative (83\%) vs. modern (17\%); their Muslim identifications ranged from extreme (17\%), moderate $(67 \%)$ to weak (17\%); and they were concerned over national unity, supporting democracy against the attempted coup and the president. Although the profile of these protesters and the content of their opinion-based identities could be different from those of the Gezi park protests, there are similarities. First, online activism was a part and promoter of protest participation like in the Gezi protests; yet this time coupled with mosque prayers calling people to streets like in the Arab spring (Unver \& Alassaad, 2016). We can also speculate about the intersectionality: Muslim identification could have different implications for conservatively- and secularly(“modern") identified participants' democratic engagement and demands. However, we 
should recognize different "democracy" conceptualizations, which could in itself entail a religious vs. secular divide.

On a cautionary note, our correlational findings reveal that opinion-based group memberships and democratic attitudes are associated but the association may work both ways. Sharing a common stance on a certain issue may contribute to participants' endorsement of democratic attitudes. Democratic attitudes can also be socialized in children and youngsters through family and school and inform participants' concerns during the protests. There is some qualitative evidence to support the former: Intergroup contact among protest participants with diverse backgrounds changed their attitudes towards minority groups, such as the Kurdish minority, for the better (Acar \& Uluğ, 2016). Finally, the possibility of reverse causality does not undermine our objective to demonstrate that the different group identities moderate the association of Muslim identification with democratic attitudes.

Another limitation concerns the sampling strategy and the use of online survey. While self-selection of people in online surveys is an issue, this could be less problematic in this study as we aimed to reach (strong to weak) supporters of the protests. It was vital to include peripherals as well as activists in our analysis to show the broad range of people who were interested and concerned over Gezi park protests and to understand how the protests impact many more people than the hardcore activists. This is an added value over other qualitative studies on Gezi park protests which focused on the "activist" identity (Acar \& Uluğ, 2016; Gümüş \& Y1lmaz, 2015). Moreover, participants’ demographic profiles and shared concerns described in this paper corresponds to those in other face-to-face surveys about the Gezi Park protests with much larger samples (Bilgiç \& Kafkasl1, 2013; KONDA, 2013). Consistency across several surveys lends support to the external validity of our findings. One final limitation is the use of single item for Muslim identification. It would be interesting to see 
how other dimensions of identification including the performative side such as religious practice are related to democratic attitudes.

Overall, this research adds to the collective action research in psychology by looking at plural opinion-based group identities in a contemporary mass protest, their intersection with Muslim identification and the role of these social identities in democratic politicization. It shows that opinion-based group identities of people in protests can be inferred from their shared concerns and action types empirically and that these plural identities intersect with religious identification as Muslim. It also highlights how the meaning of Muslim identity and its relationship to democratic engagement is culturally-embedded. Thus, Muslim identity is not a monolithic identity; it has different meanings and consequences for democratic attitudes. 


\section{References}

Acar, Y. G. \& Uluğ, Ö. M. (2016). Exploring prejudice reduction through solidarity and togetherness experiences among Gezi Park activists. Journal of Social and Political Psychology, 4(1), 166-179. doi:10.5964/jspp.v4i1.547

Ariely, G. \& Davidov, E. (2011). Can we rate public support for democracy in a comparable way? Cross-national equivalence of democratic attitudes in the World Value Survey. Social Indices Research, 104, 271-286. doi:10.1007/s11205-010-9693-5

Bilgiç, E. E. \& Kafkasl1, Z. (2013, Jun 4). Results of a survey among Gezi park protesters [Gezi Parkı direnişçileriyle yapılan anketten çıkan sonuçları]. T24 News Channel. Retrieved in June 2013 from http://t24.com.tr/haber/gezi-parki-direniscileriyleyapilan-anketten-cikan-ilginc-sonuclar/231335

Bliuc, A.M., McGarty, C., Reynolds, K. J., \& Muntele, O. (2007). Opinion-based group membership as a predictor of commitment to political action. European Journal of Social Psychology, 37, 19-32. doi: 10.1002/ejsp.334

Clemm, W. (2011, March 3). The flowering of an unconventional revolution. South China Morning Post International Edition. http:/www.scmp.com/article/739685/floweringunconventional-revolution

Çelik, E. (2015). Negotiating religion at the Gezi park protests. I. David and K. F. Toktamış (Eds.), Everywhere Taksim: Sowing the seeds for a new Turkey at Gezi (185-200). Amsterdam: Amsterdam University Press.

Deaux, K. (2001). Social identity. In J. Worrell (Ed.), Encyclopedia of women and gender (Vol. 2, 1059-1067). San Diego, CA: Academic Press.

Drury J. \& Reicher S. (2000). Collective action and psychological change: The emergence of new social identities. British Journal of Social Psychology, 39, 579 -604. Doi: $10.1348 / 014466600164642$ 
European Values Survey (2008). European Values Survey [Questionnaire] Retrieved from http://www.europeanvaluesstudy.eu/

Farro, A. L. \& Demirhisar, G. D. (2014). The Gezi Park movement: A Turkish experience of the twenty-first-century collective movements. International Review of Sociology, 24(1), 176-189. doi: 10.1080/03906701.2014.894338

Feldman, S. (2003). Enforcing social conformity: A theory of authoritarianism. Political Psychology, 24(1), 41-73. doi: 10.1111/0162-895X.00316

Field, A. (2015). Discovering Statistics Using IBM SPSS Statistics ( $4^{\text {th }}$ Ed.). London: Sage

Fleischmann, F., \& Phalet, K. (2016). Identity conflict or compatibility: A comparison of Muslim minorities in five European cities, Political Psychology, 37(4), 447-463. doi: 10.1111/pops. 12278

Fleischmann, F., Phalet, K. \& Swyngedouw, M. (2013). Dual identity under threat: when and how do Turkish and Moroccan minorities engage in politics? Zeitschrift für Psychologie, 221(4), 214-222. http://dx.doi.org/10.1027/2151-2604/a000151

Gümüş, P. \& Yılmaz, V. (2015). Where did Gezi come from? I. David \& K. F. Toktamış (Eds.), Everywhere Taksim: Sowing the seeds for a new Turkey at Gezi (215-230). Amsterdam: Amsterdam University Press.

Inglehart, R., \& Catterberg, G. (2002). Trends in political action: The developmental trend and the post-honeymoon decline. International Journal of Comparative Sociology, 43, 300-316. doi: 10.1177/002071520204300305

Inglehart, R \& Norris, P. (2003). The true clash of civilizations. Foreign Policy, 135, 62-70. doi: $10.2307 / 3183594$

Jamal, A. \& Tessler, M. (2008). Attitudes in the Arab World. Journal of Democracy, 19(1), 97-110.

Klandermans, B. (1997). The social psychology of protest. Oxford: Blackwell. 
Klandermans, B., Van der Toorn, J., \& Van Stekelenburg, J. (2008). Embeddedness and identity: how immigrants turn grievances into action. American Sociological Review, 73(6), 992-1012. doi: 10.1177/000312240807300606

Klein, O., Russell, S., \& Reicher, S. (2007). Social identity performance: Extending the strategic side of SIDE. Personality and Social Psychology Review, 11, 1-18. doi: $10.1177 / 1088868306294588$

KONDA (2013). Gezi Park Survey: Who are they, why are they here, and what do they want? [Gezi Parki araştirmasi: Kimler, neden oradalar ve ne istiyorlar?]. Survey report retrieved in June 2013 from http://www.konda.com.tr/

KONDA (2016). Survey report of protesters in the "Democracy Watch" [Demokrasi Nöbeti araştırmas1]. Survey report retrieved in Sep 2016 from http://www.konda.com.tr/

McCutcheon, A. C. (1987). Latent class analysis. Beverly Hills: Sage Publicaitons.

McGarty, C., Bliuc, A. M., Thomas, E. F., \& Bongiorno, R. (2009). Collective action as the material expression of opinion-based group membership. Journal of Social Issues, 65(4), 839-857. doi: 10.1111/j.1540-4560.2009.01627.x

McGarty, C., Thomas, E., Lala, G., Smith, L. \& Bliuc, A.M. (2014). New technologies, new identities and the growth of mass opposition in the 'Arab Spring'. Political Psychology, 35, 725-740. doi: 10.1111/pops.12060

Milkman, R. (2014). Millennial Movements. Dissent, 61(3), 55-59. doi: $10.1353 /$ dss. 2014.0053

Muthén, L. K., \& Muthén, B. O. (1998-2012). Mplus User's Guide. Sixth Edition. Los Angeles, CA: Muthén \& Muthén Retrieved from http://www.statmodel.com/

Nylund, K.L., Asparouhov. T. \& Muthén, B. (2007). Deciding on the number of classes in latent class analysis and growth mixture modeling: A Monte Carlo simulation study. Structural Equation Modeling, 14, 535-569. 
Postmes, T., Bezouw, M. van, \& Kutlaca, M . (2014). From collective discontent to largescale public disorder. Groningen: Groningen University.

Postmes, T., Haslam, S. A., \& Jans, L. (2013). A single-item measure of social identification: Reliability, validity, and utility. British Journal of Social Psychology, 52(4), 597-617. doi: 10.1111/bjso.12006

Postmes, T., Haslam, S.A. \& Swaab, R. (2005). Social influence in small groups: An interactive model of social identity formation. European Review of Social Psychology, 16(1), 1-42. doi: 10.1080/10463280440000062

Preacher, K. J., Curran, P. J., \& Bauer, D. J. (2006). Computational tools for probing interaction effects in multiple linear regression, multilevel modeling, and latent curve analysis. Journal of Educational and Behavioral Statistics, 31, 437-448.

Reicher, S. (1996). 'The Battle of Westminster': Developing the social identity model of crowd behaviour in order to explain the initiation and development of collective conflict. European Journal of Social Psychology, 26, 115-34. doi: 10.1002/(SICI)1099-0992(199601)26:1<115::AID-EJSP740>3.0.CO;2-Z

Reicher, S. (2001). The psychology of crowd dynamics. In M.A. Hogg and R.S. Tindale (Eds.), Blackwell handbook of social psychology: Group processes (182-208). Oxford: Blackwell.

Schumann, S. \& Klein, O. (2015). Substitute or stepping stone? Assessing the impact of lowthreshold online collective actions on offline participation. European Journal of Social Psychology, 45, 308-322. doi: 10.1002/ejsp.2084

Simon, B., Klandermans, B. (2001). Towards a social psychological analysis of politicized collective identity: Conceptualization, antecedents, and consequences. American Psychologist, 56(4), 319-331. doi:10.1037/0003-066X.56.4.319 
Simon, B. \& Ruhs, D. (2008). Identity and politicization among Turkish migrants in Germany: The role of dual identification. Journal of Personality and Social Psychology, 95, 1354-1366. doi:10.1037/0003-066X.56.4.319

Snow, D. A., Rochford, E. B., Worden, S. K. \& Benford, R. D. (1986). Frame alignment processes, micromobilization, and movement participation. American Sociological Review, 51(4), 464-81.

Tessler, M. (2002). Do Islamic orientations influence attitudes toward democracy in the Arab world? Evidence from Egypt, Jordan, Morocco, and Algeria. International Journal of Comparative Sociology, 43(3-5), 229-249. doi: 10.1177/002071520204300302

The Integration of European Second-Generation Survey Belgium (2008). Centre for Sociology and Centre for Social and Cultural Psychology University of Leuven [Codebook].

Thomas, E.F., Mavor, K. I. \& McGarty, C. (2012). Social identities facilitate and encapsulate action-relevant constructs: A test of the social identity model of collective action. Group Processes \& Intergroup Relations, 15(1), 75-88. doi: $10.1177 / 1368430211413619$

Thomas, E. F., McGarty, C., Lala, G., Stuart, A., Hall, L. j., \& Goddard, A. (2015). Whatever happened to Kony2012? Understanding a global Internet phenomenon as an emergent social identity. European Journal of Social Psychology, 45, 356-367. doi: 10.1002/ejsp.2094

Thomas, E.F., McGarty, C. \& Mavor, K. I. (2009). Aligning identities, emotions, and beliefs to create commitment to sustainable social and political action. Personality and Social Psychology Review, 13(3), 194-218. doi: 10.1177/1088868309341563

Unver, H. A. \& Alassaad, H. (2016, Sep 14). How Turks mobilized against the coup: The power of the mosque and the hashtag. Foreign Affairs. Retrieved from 
https://www.foreignaffairs.com/articles/2016-09-14/how-turks-mobilized-against-

$\underline{\text { coup }}$

van Stekelenburg, J. \& Klandermans, B. (2013). The social psychology of protest. Current Sociology, 61, 886-905. doi: 10.1177/0011392113479314

van Stekelenburg J., Klandermans, B. \& van Dijk, W. W. (2009). Context matters: Explaining why and how mobilizing context influences motivational dynamics. Journal of Social Issues, 65, 815-838. doi: 10.1111/j.1540-4560.2009.01626.x

van Zomeren, M., Postmes, T., \& Spears, R. (2008). Toward an integrative Social Identity Model of Collective Action: A quantitative research synthesis of three sociopsychological perspectives. Psychological Bulletin, 134, 504-535. doi:10.1037/00332909.134.4.504

Varol, O., Ferrara, E., Ogan, C. L., Menczer, F., \& Flammini, A. (2014). Evolution of online user behavior during a social upheaval. Proceedings of the 2014 ACM Conference on Web Science, 81-90. http://dl.acm.org/citation.cfm?id=2615699

Verkuyten, M. (2007). Religious group identification and inter-religious relations: A study among Turkish-Dutch Muslims. Group Processes and Intergroup Relations, 10(3), 341-357. doi: 10.1177/1368430207078695

Verkuyten, M.J.A.M. \& Slooter, L.A. (2008). Muslim and non-Muslim adolescents' reasoning about freedom of speech and minority rights. Child Development, 79, 514528. doi: 10.1111/j.1467-8624.2008.01140.x

Walsh, E. J. (1981). Resource mobilization and citizen protest in communities around Three Mile Island. Social Problems, 29, 1-21. doi: http://dx.doi.org/10.2307/800074 Weber, C. \& Federico, C. (2007). Interpersonal attachment and patterns of ideological belief. Political Psychology, 28, 389-416. doi: 10.1111/j.1467-9221.2007.00579.x 
Wright, S. C., Taylor , D. M., \& Moghaddam, F. M. (1990). Responding to membership in a disadvantaged group: From acceptance to collective protest. Journal of Personality and Social Psychology, 58, 994-1003. http://dx.doi.org/10.1037/0022-3514.58.6.994 


\section{Footnote}

${ }^{1}$ The exact wordings of the concerns were: 'I was/am concerned/worried over'... 'gentrification and harmful environmental policies, including Gezi park, third bridge', 'tense international relations with neighbor countries (shortened as foreign policy)', 'deterioration of democracy', 'deterioration of principals and reforms of Atatürk' (shortened as national unity), 'deterioration of laicite', 'deterioration of economy', 'deterioration and restriction of women's rights', 'negative attitudes towards and the crackdown on LGBT people', 'deterioration of the situation of minorities', 'the recent reconciliation policies leading to ethnic separatism', 'deterioration of Islamic values', 'authoritarian attitudes of the government and the prime minister', 'brute force use by police during the protests', 'the provocateurs during the protests'. Italicized words are the labels shown in Figure 1.

${ }^{2}$ Atatürk is one of the founding fathers of Turkish Republic and his principals and reforms go beyond national unity and include French-style laicite and patriotism among others. A detailed discussion of these reforms is beyond the scope of this paper.

${ }^{3}$ The four-class model also provided a theoretically better fit for the data since the five-class model differentiated secularists further into two-classes, which was beyond the scope of this paper.

${ }^{4}$ Mplus 7 calculates robust standard errors for MLR analysis separately for each probability — separate standard errors for the probability of agreeing and strongly agreeing. In the Figure, the higher standard errors (generally those of strongly agreeing) were shown.

${ }^{5}$ For the remaining comparisons, chi-square model difference test was used by setting equal the latent mean differences. Liberals were significantly different from moderates $\left(\chi^{2}(1)=\right.$ $8.402, p<.01)$ and all were significantly different from conservatives $\left(\chi^{2}(2)=17.064, p<\right.$ $.001)$ 


\begin{tabular}{|c|c|c|c|c|c|c|c|c|c|c|}
\hline \multirow[b]{2}{*}{$\begin{array}{l}\text { Variables of the } \\
\text { Study }\end{array}$} & \multirow[b]{2}{*}{$\begin{array}{l}\% \text { or } \\
\text { Mean } \\
\text { (SD) }\end{array}$} & \multirow[b]{2}{*}{ CNT2 } & \multirow[b]{2}{*}{ CNT3 } & \multirow[b]{2}{*}{ Muslim } & \multirow[b]{2}{*}{ Democ. } & \multirow[b]{2}{*}{ FreeSp. } & \multirow[b]{2}{*}{ Author. } & \multicolumn{3}{|c|}{$\begin{array}{c}\text { Intergroup Attitudes: } \\
\text { Distance }\end{array}$} \\
\hline & & & & & & & & $\begin{array}{l}\text { Rel. } \\
\text { Min. }\end{array}$ & $\begin{array}{l}\text { Ethn. } \\
\text { min }\end{array}$ & $\begin{array}{l}\text { Marg. } \\
\text { min }\end{array}$ \\
\hline CONTRAST1: & 62.5 & & & & & & & & & \\
\hline Lib.-Sec. vs. & & & & & & & & & & \\
\hline Mod.-Cons. & $37.5 \%$ & $-.231^{* *}$ & $-.417^{* *}$ & $-.298^{* *}$ & $.120^{* *}$ & $.415^{* *}$ & $-.269^{* *}$ & $-.223^{* *}$ & $-.129^{* *}$ & $-.247^{* *}$ \\
\hline $\begin{array}{l}\text { CONTRAST2: } \\
\text { Lib. vs. Sec. }\end{array}$ & $\begin{array}{l}20 \text { vs. } \\
42.6 \%\end{array}$ & & $.096^{*}$ & $-.225^{* *}$ & .002 & .063 & $-.130^{* *}$ & -.027 & $-.199^{* *}$ & $-.100^{*}$ \\
\hline $\begin{array}{l}\text { CONTRAST3: } \\
\text { Mod. vs. Cons. } \\
\text { Muslim }\end{array}$ & $\begin{array}{l}28 \text { vs. } \\
9.5 \% \\
3.87\end{array}$ & & & $-.086^{*}$ & -.011 & .061 & $-.111^{* *}$ & $-.159^{* *}$ & .056 & $-.176^{* *}$ \\
\hline Democracy & $\begin{array}{l}(2.31) \\
4.03\end{array}$ & & & & -.019 & $-.485^{* *}$ & $.310^{* *}$ & $.280^{* *}$ & $.277^{* *}$ & $.379^{* *}$ \\
\hline Free Speech & $\begin{array}{l}(0.65) \\
4.28\end{array}$ & & & & & $.132^{* *}$ & $-.266^{* *}$ & $-.116^{* *}$ & -.052 & -.047 \\
\hline & $(0.73)$ & & & & & & $-.387^{* *}$ & $-.263^{* *}$ & $-.248^{* *}$ & $-.388^{* *}$ \\
\hline Authoritarianism & $\begin{array}{l}1.70 \\
(0.72)\end{array}$ & & & & & & & $.339^{* *}$ & $.292^{* *}$ & $.316^{* *}$ \\
\hline Distance & & & & & & & & & & \\
\hline Religious min & $\begin{array}{l}0.06 \\
(0.19)\end{array}$ & & & & & & & & $.489^{* *}$ & $.447^{* *}$ \\
\hline Ethnic min & $\begin{array}{l}0.28 \\
(0.37)\end{array}$ & & & & & & & & & $.416^{* *}$ \\
\hline Marginal min & $\begin{array}{l}0.22 \\
(.36)\end{array}$ & & & & & & & & & \\
\hline
\end{tabular}

Table 2. LCAs with 2 to 5 Classes

\begin{tabular}{lllll}
\hline Model Fit Indices & 2 class & 3-class & 4-class & 5-class \\
\hline Log Likelihood & -16464.998 & -15798.918 & -15423.359 & -15423.4 \\
AIC & 33185.997 & 31977.836 & 31350.719 & 31067.35 \\
BIC & 33758.061 & 32826.994 & 32476.97 & 32470.7 \\
Entropy & 0.993 & 0.926 & 0.932 & 0.922 \\
Bootstrap Likelihood ratio test & 1 vs. 2 & 2 vs. 3 & 3 vs.4 & 4 vs. 5 \\
(BLRT) & 2881.164 & 1332.161 & 751.118 & 407.366 \\
& $\mathrm{p}<.001$ & $\mathrm{p}<.001$ & $\mathrm{p}<.001$ & $\mathrm{p}<.001$ \\
n for each class & $\mathrm{C} 1=570$ & $\mathrm{C} 1=66$ & $\mathrm{C} 1=60$ & $\mathrm{C} 1=130$ \\
& $\mathrm{C} 2=75$ & $\mathrm{C} 2=210$ & $\mathrm{C} 2=183$ & $\mathrm{C} 2=59$ \\
& & $\mathrm{C} 3=369$ & $\mathrm{C} 3=129$ & $\mathrm{C} 3=169$ \\
& & & $\mathrm{C} 4=273$ & $\mathrm{C} 4=150$ \\
& & & & $\mathrm{C} 5=137$ \\
\hline
\end{tabular}


Table 3. Separate Regression Analyses showing the Relationship of Opinion-based Group Identities and Muslim Identification with Democratic Attitudes

\begin{tabular}{lllll}
\hline Predictors & Democracy & Free Speech & Authoritarianism & Intergroup Attitudes \\
\hline $\begin{array}{l}\text { Contrast1: Liberals- } \\
\text { Secularists vs. }\end{array}$ & & & & \\
$\begin{array}{l}\text { Moderates- } \\
\text { Conservatives }\end{array}$ & $.058(.017)^{* *}$ & $.142(.024)^{* * *}$ & $-.111(.026)^{* * *}$ & $-.013(.005)^{*}$ \\
$\begin{array}{l}\text { Contrast2: Liberals } \\
\text { vs. secularists }\end{array}$ & & & & \\
$\begin{array}{l}\text { Contrast3: } \\
\text { Moderates- }\end{array}$ & $.026(.038)$ & $.102(.045)^{*}$ & $-.180(.049)^{* * *}$ & $-.029(.010)^{* *}$ \\
conservatives & $.074(.052)$ & $.176(.085)^{*}$ & $-.194(.093)^{*}$ & $-.018(.019)$ \\
Muslim & & & & \\
Contrast1*Muslim & $.022(.013)$ & $-.115(.018)^{* * *}$ & $.059(.020)^{* *}$ & $.025(.004)^{* * *}$ \\
Contrast2*Muslim & $\mathrm{ns}$ & $.023(.009)^{*}$ & $-.023(.010)^{*}$ & $-.007(.002)^{* *}$ \\
Contrast3*Muslim & $\mathrm{ns}$ & $.003(.019)$ & $-.004(.021)$ & $-.003(.004)$ \\
Age & $\mathrm{ns}$ & $.010(.031)$ & $-.035(.034)$ & $-.019(.007)^{* *}$ \\
\hline Intercept & $.012(.004)^{* *}$ & $\mathrm{Ns}$ & $\mathrm{ns}$ & $\mathrm{ns}$ \\
& 3.664 & 4.227 & 1.714 & $0.050($ Rel. min) \\
& & & & $0.214($ Ethnic min) \\
\hline R2 & $0.037^{*}$ & $.357^{* * *}$ & $.197^{* * *}$ & $.348^{*}$ \\
\hline
\end{tabular}

Note. Non-significant variables were dropped from the analyses, denoted as ns.

$* p<.05, * * p<.01, * * * p<.001$ 


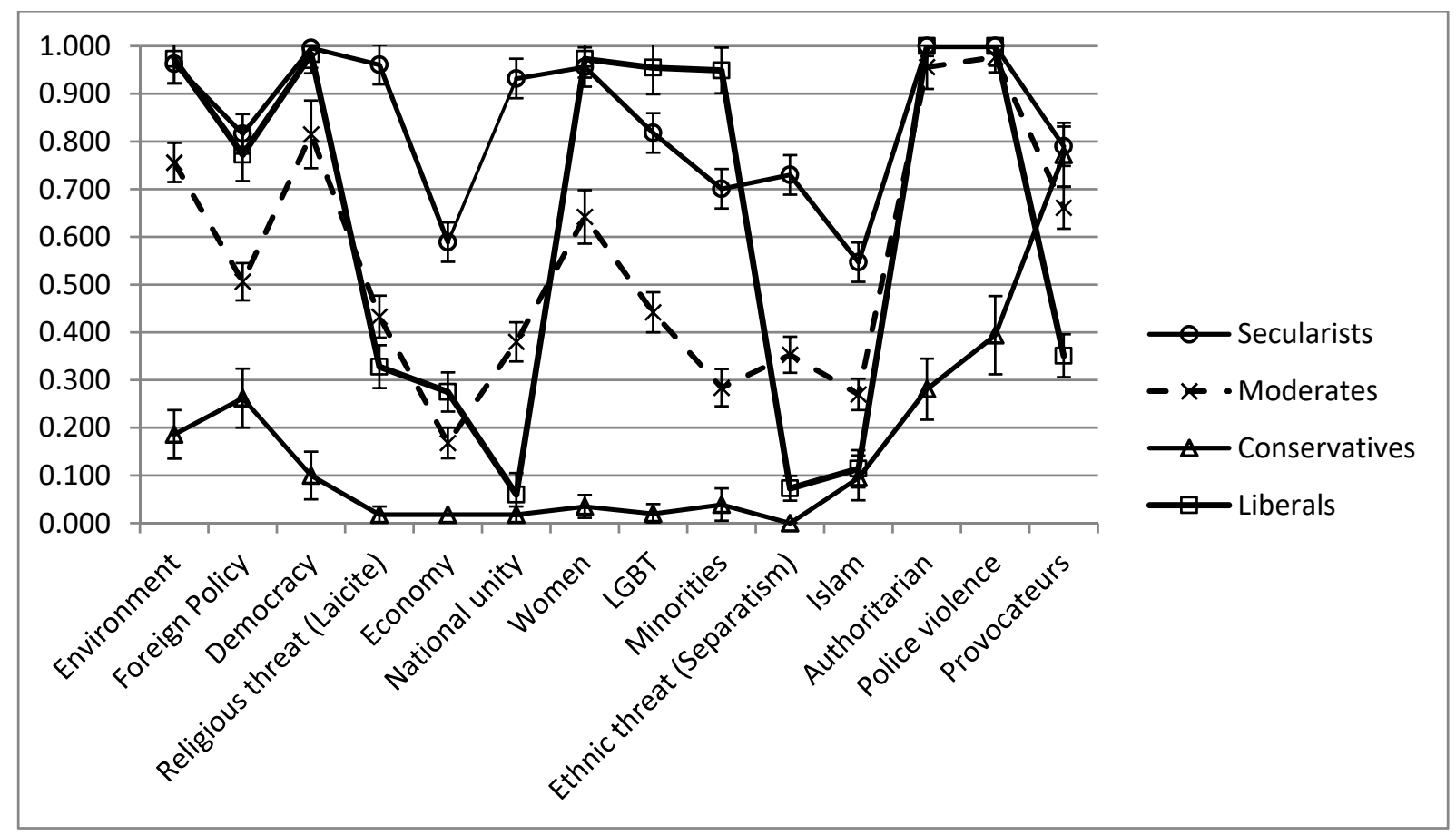

Figure 1. Summed probability of agreeing and totally agreeing to the concerns by different identities (with standard error bars)

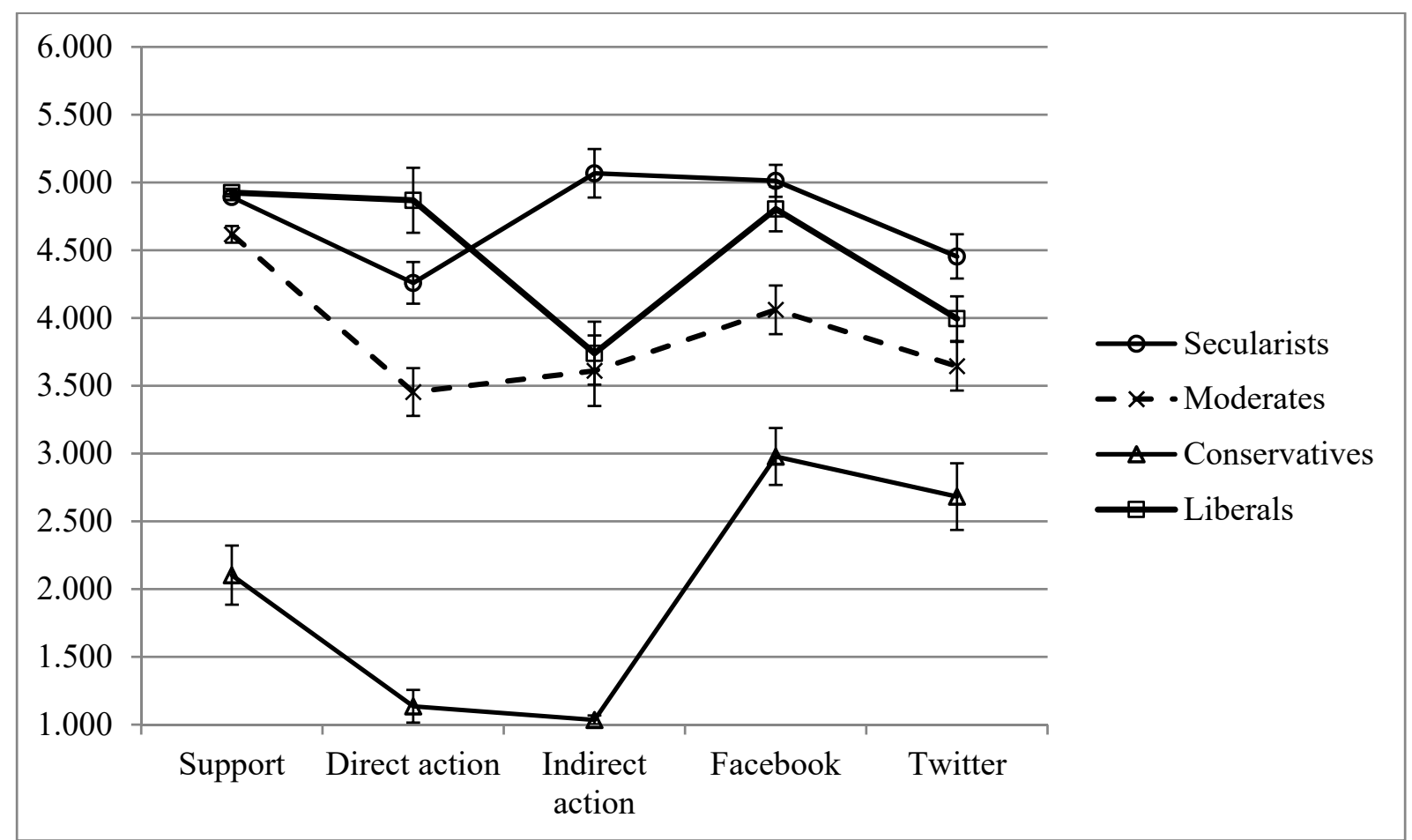

Figure 2. Levels and types of action in the protests by different identities (with standard error bars) 


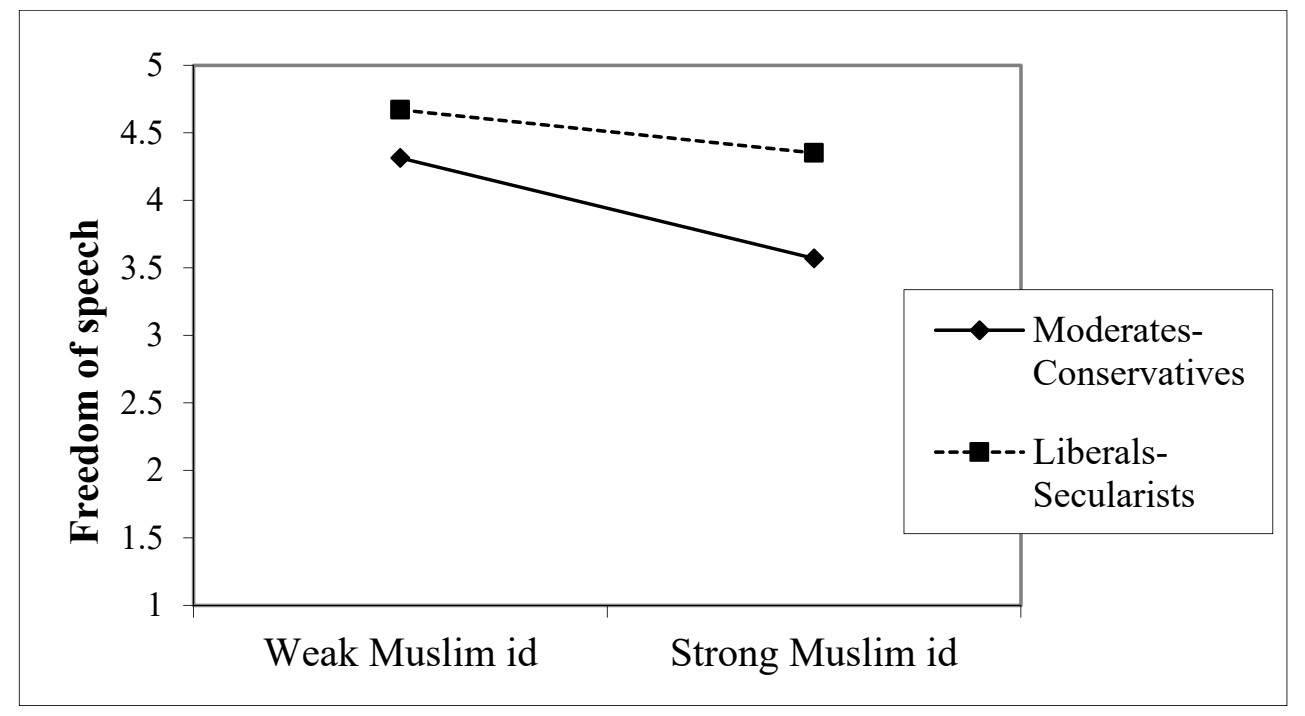

Figure 3. Interaction between Muslim Identification and Contrast 1 (Liberals \& Secularists vs. Moderates \& Conservatives) on Freedom of Speech

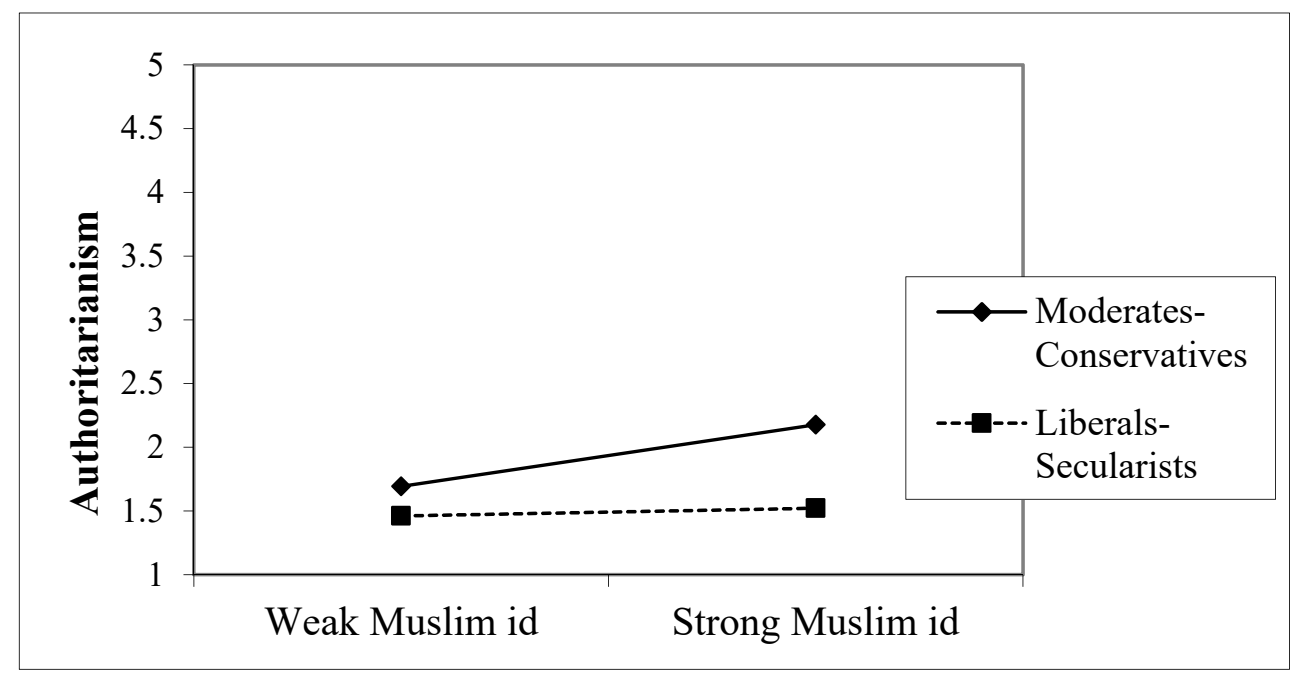

Figure 4. Interaction between Muslim Identification and Contrast 1 (Liberals \& Secularists vs. Moderates \& Conservatives) on Authoritarianism 


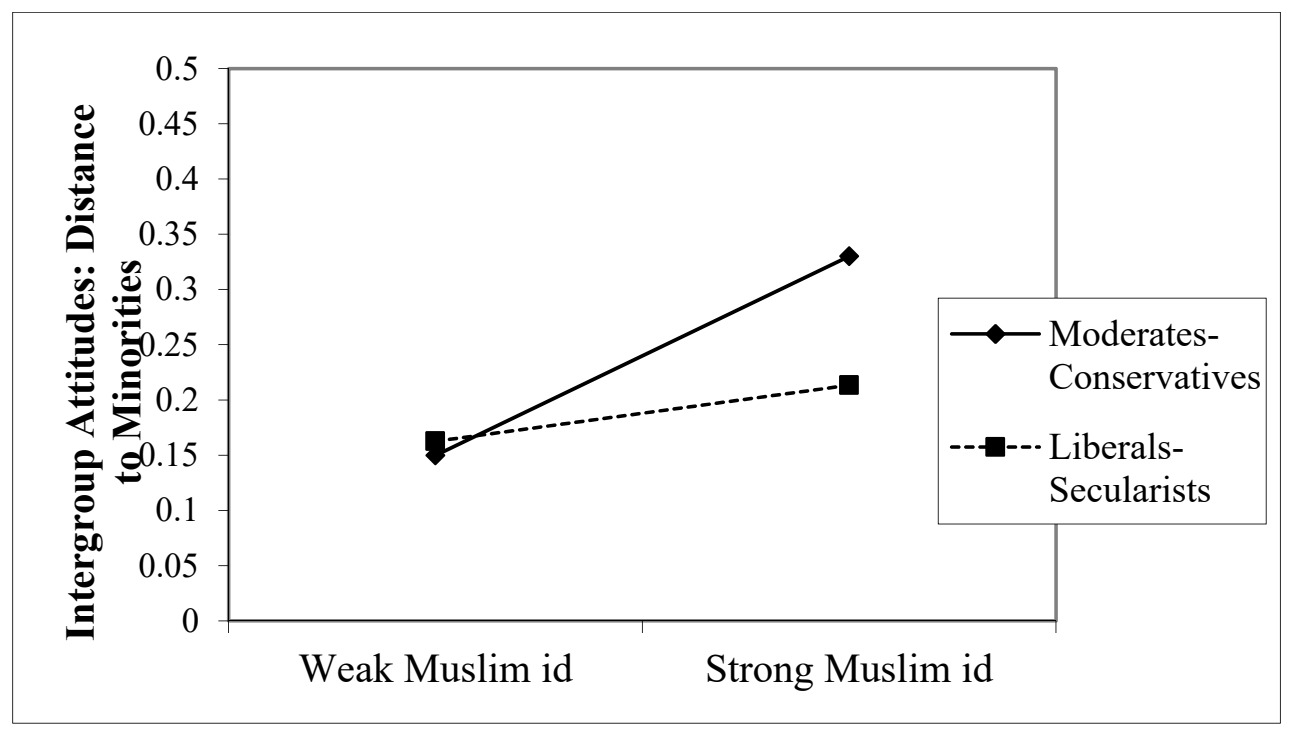

Figure 5. Interaction between Muslim Identification and Contrast 1 (Liberals \& Secularists vs. Moderates \& Conservatives) on Distance towards Minorities

Note. The intercept of the distance towards ethnic minorities was used, as the latent intercept was not calculated 


\section{Supplemental Online Material}

Figures showing Fit Statistics for 2 to 5 Latent Class Solutions

\begin{tabular}{|c|c|c|c|c|}
\hline \multicolumn{5}{|c|}{ Log Likelihood } \\
\hline-15000 & 2 class & 3 -class & 4-class & 5-class \\
\hline-15200 & & & & \\
\hline-15400 & & & & \\
\hline-15600 & & & & \\
\hline-15800 & & & & \\
\hline-16000 & & & & \\
\hline-16200 & & & & \\
\hline-16400 & & & & \\
\hline-16600 & & & & \\
\hline
\end{tabular}

Figure 1. Supplementary Material. Log Likelihood Results for 2 to 5 Latent Class Solutions

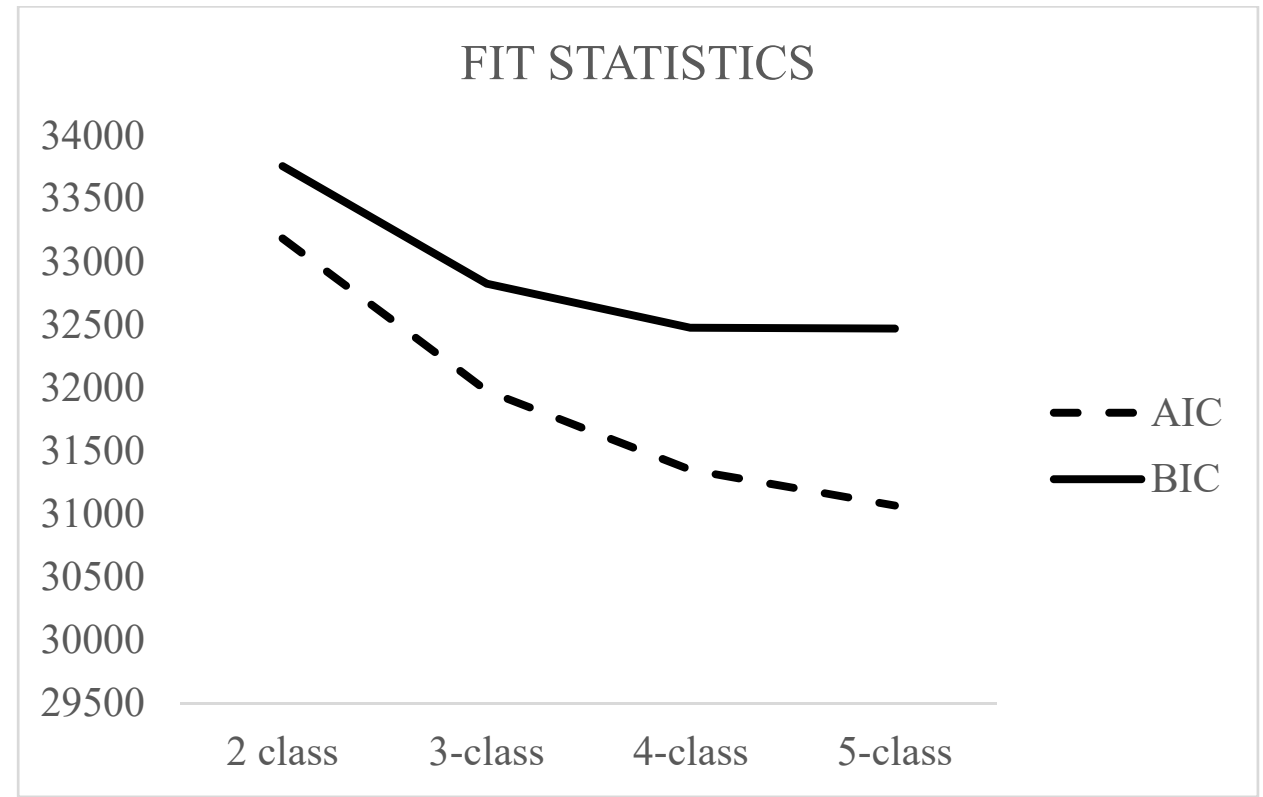

Figure 2. Supplementary Material. Fit Statistics for 2 to 5 Latent Class Solutions 


\section{Importance of Concerns and Actions}

\section{in Predicting Opinion-based Group Identities}

In terms of the importance of predictors (i.e., concerns and action) in LCA, those concerns and actions that differentiate well across the four latent classes can be considered better predictors; but LCA does not provide any quantitative distinctions. We also conducted a 2-step cluster analysis to provide information about predictor importance. The two groupings by LCA and 2-step cluster analysis substantially overlap $(\mathrm{r}=.87, \mathrm{p}<.001)$. Cluster compositions were: Liberals (22\%) secularists (35\%), moderates (32\%) and conservatives $(12 \%)$. We thus believe that results of 2-step cluster analysis can provide useful information regarding the importance of the predictors that we can only qualitatively infer in LCA. Protest-based concerns did not differentiate well between the clusters as well as those concerns about foreign policy, Islam and economy. Action forms did not differentiate well either particularly social media activism.

Table 1. Supplementary Material.

\begin{tabular}{ll} 
Predictor Importance & \\
\hline Religious threat (Laicite) & 1.00 \\
National unity & 0.94 \\
Women & 0.88 \\
LGBT & 0.80 \\
Minorities & 0.75 \\
Democracy & 0.71 \\
Environment & 0.70 \\
Support & 0.69 \\
Ethnic threat (Separatism) & 0.57 \\
Authoritarian & 0.49 \\
Economy & 0.48 \\
Foreign Policy & 0.43 \\
Police violence & 0.40 \\
Islam & 0.29 \\
Indirect action & 0.16 \\
Direct Action & 1.50 \\
Provocateurs & 0.15 \\
Social Media-Facebook & 0.07 \\
Social Media-Twitter & 0.03 \\
\hline
\end{tabular}




\section{Opinion-based Group Identities (based on Concerns) Predicting Action Forms}

Theoretically, the aim of the paper was to present typologies/configurations of action motives/concerns and forms to elucidate processes of selective alignment through joint participation in the action, rather than predicting behavior from these concerns/motives. This, however, provides only a qualitative discussion of how motives are communicated through particular actions so they are entwined in the formation of opinion-based group identities. It is also possible to delineate these identities using only concerns in LCA to test the association between the group identities and action forms statistically. First, LCA solution with four classes using only concerns gave a very similar composition of these identities (see Table 2 below for cross-tab). Second, results of the regression analyses supported the discussion in the paper (see Table 3 below): Liberals and secularists were more active in all the types of action forms compared to moderates and conservatives; the difference between secularists and liberals lied in the type of participation so that the former preferred indirect participation while the latter preferred direct participation more; and moderates were also more active than conservatives but the difference was smaller with regards to social media activism.

Table 2. Supplementary Material. Cross-Tab of LCA solutions using only Concerns vs. Concerns and actions

\begin{tabular}{lrrrrr}
$\begin{array}{l}\text { Opinion-based } \\
\text { Group Identities: } \\
\text { Concerns and }\end{array}$ & \multicolumn{1}{c}{ Lerrats } \\
Actions & Secularists & Moderates & Conservatives & Liberals \\
\hline Secularists & 253 & 14 & 0 & 5 & 272 \\
Moderates & 3 & 165 & 13 & 1 & 182 \\
Conservatives & 0 & 7 & 50 & 0 & 57 \\
Liberals & 1 & 3 & 0 & 125 & 129 \\
Total & 257 & 189 & 63 & 131 & 640 \\
\hline
\end{tabular}

\section{Opinion-based Group Identities: ONLY Concerns}

Group Identities:

Concerns and 
Table 3. Supplementary Material. Multivariate Regression Analysis with Opinion-based Group Identities as Predictors (based on concerns) and Action Forms as Dependent Variables

\begin{tabular}{|c|c|c|c|c|c|}
\hline Predictors & Support & $\begin{array}{l}\text { Direct } \\
\text { Participation }\end{array}$ & $\begin{array}{l}\text { Indirect } \\
\text { Participation }\end{array}$ & $\mathrm{FB}$ & Twitter \\
\hline $\begin{array}{l}\text { Contrast1: Liberals- } \\
\text { Secularists vs. } \\
\text { Moderates- } \\
\text { Conservatives }\end{array}$ & $.325(.014)^{* * *}$ & $.492(.047)^{* * *}$ & $.449(.054)^{* * *}$ & $.281(.040)^{* * *}$ & $.215(.049)^{* * *}$ \\
\hline $\begin{array}{l}\text { Contrast2: Liberals vs. } \\
\text { secularists }\end{array}$ & $.023(.497)$ & $.299(.111)^{* *}$ & $-.539(.127)^{* * *}$ & $-.086(.095)$ & $-.167(.118)$ \\
\hline $\begin{array}{l}\text { Contrast3: Moderates } \\
\text { vs. conservatives }\end{array}$ & $.953(.046)^{* * *}$ & $.962(.150)^{* * *}$ & $1.249(.173)^{* * *}$ & $.340(.128)^{* *}$ & $.364(.159)^{*}$ \\
\hline Intercept & 4.254 & 3.534 & 3.480 & 4.314 & 3.770 \\
\hline $\mathrm{R} 2$ & $.516^{* * *}$ & $.155^{* * *}$ & $.157^{* * *}$ & $.080^{* * *}$ & $.037^{*}$ \\
\hline
\end{tabular}

\section{Linear Trend Analyses for Opinion-based Group Identities, and its Interaction with}

\section{Muslim Identification on Democratic Attitudes}

In the paper we used orthogonal contrast coding for recoding the group identities for regression analysis. One can also recode the identities with a linear trend coding: Liberals (2), secularists (1), moderates (-1), and conservatives (-2). Table 2 shows the results of separate regression analyses on democratic attitudes with the linear trend coding of these identities, Muslim identification and their interactions as predictors. The main effects of the linear trend on democratic attitudes were significant showing that there was an increasing endorsement of democracy and freedom of speech and decreasing endorsement of authoritarianism and distance to minorities from liberals, secularists, moderates to conservatives. Similar to the results in the paper, the interactions between the identities coded as linear trend and Muslim identification were significant for freedom of speech, authoritarianism and intergroup attitudes. In order to graph the interactions, the means were calculated for $+1 \mathrm{SD}$ and $-1 \mathrm{SD}$ for Muslim identification. As seen in the Figures 1-3, the relationship of Muslim identification with democratic attitudes gets stronger from liberals to secularists to moderates to 
conservatives. We can also see that secularists and liberals on the one hand, and moderates and conservatives on the other show similar patterns to each other

Table 4. Supplementary Material. Separate Regression Analyses showing the Relationship of Opinion-based Group Identities (Linear Trend), and Muslim Identification with Democratic Attitudes

\begin{tabular}{lllll}
\hline Predictors & Democracy & Free Speech & Authoritarianism & Intergroup Attitudes \\
\hline Linear Trend & $.072(.022)^{* *}$ & $.181(.020)^{* * *}$ & $-.143(.022)^{* * *}$ & $-.023(.005)^{* * *}$ \\
Muslim & $.022(.013)$ & $-.119(.012)^{* * *}$ & $.065(.013)^{* * *}$ & $.023(.003)^{* * *}$ \\
LinearTrend*Muslim & $\mathrm{ns}$ & $.036(.008)^{* * *}$ & $-.028(.009)^{* *}$ & $-.007(.002)^{* *}$ \\
Age & $.012(.004)^{* *}$ & $\mathrm{~ns}$ & $\mathrm{~ns}$ & $\mathrm{~ns}$ \\
Intercept & 3.679 & 4.256 & 1.712 & 0.058 (Religious min) \\
& & & & 0.227 (Ethnic min) \\
& & & $.166^{* * *}$ & $0.266($ Marginal min) \\
R2 & $0.034^{*}$ & $.352^{* * *}$ & $.348^{*}$ \\
\hline
\end{tabular}

Note. Linear trend coding: Liberals (2), Secularists (1), Moderates (-1), Conservatives (-2) $* \mathrm{p}<.05, * * \mathrm{p}<.01, * * * \mathrm{p}<.001$

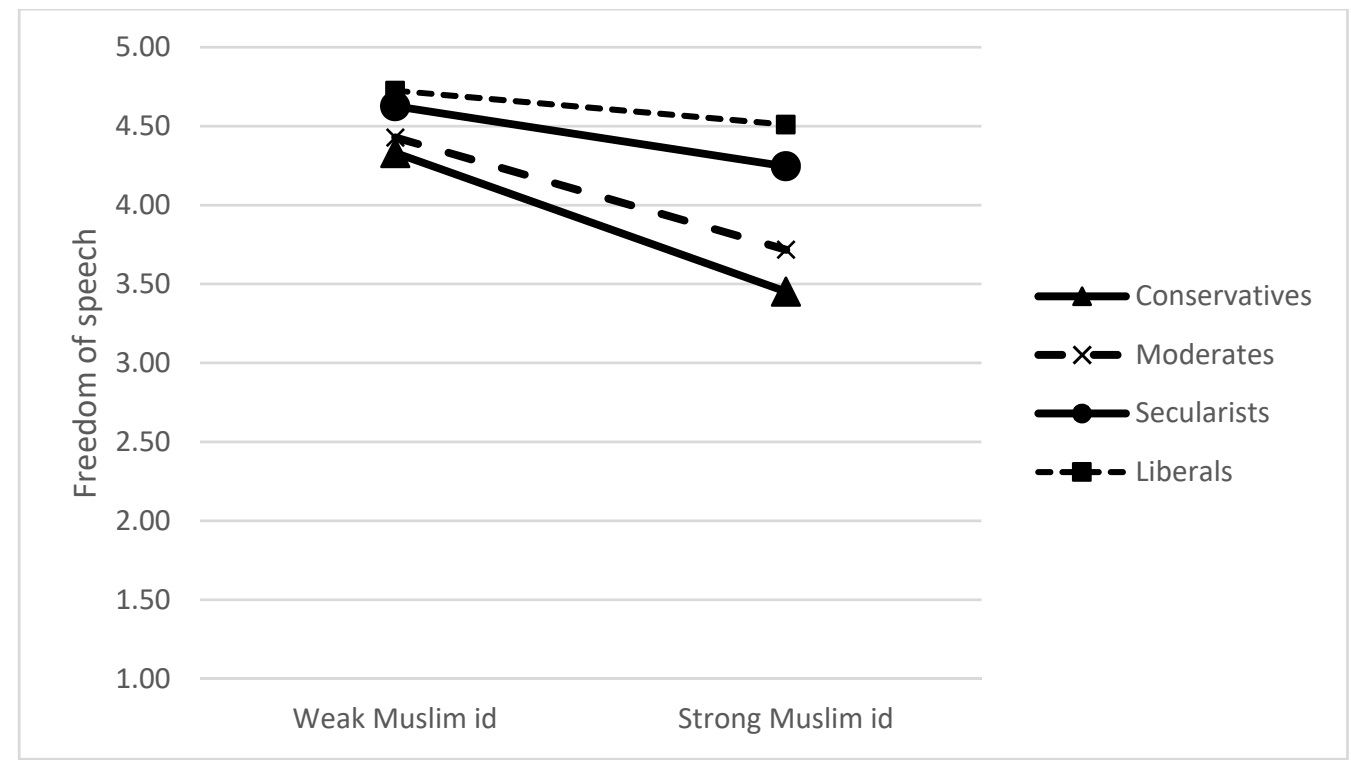

Figure 3. Supplementary Material. The interaction between Muslim identification and linear trend on Freedom of Speech 


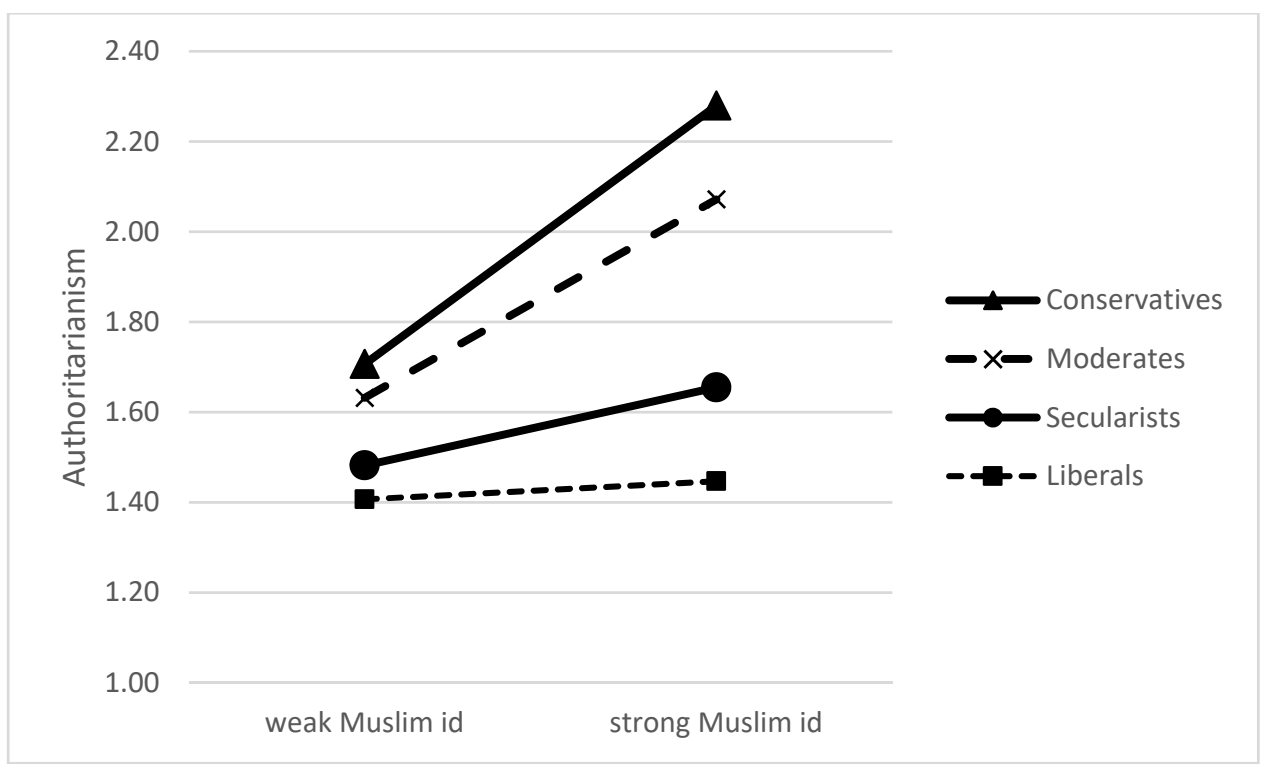

Figure 4. Supplementary Material. The interaction between Muslim identification and linear trend on Authoritarianism

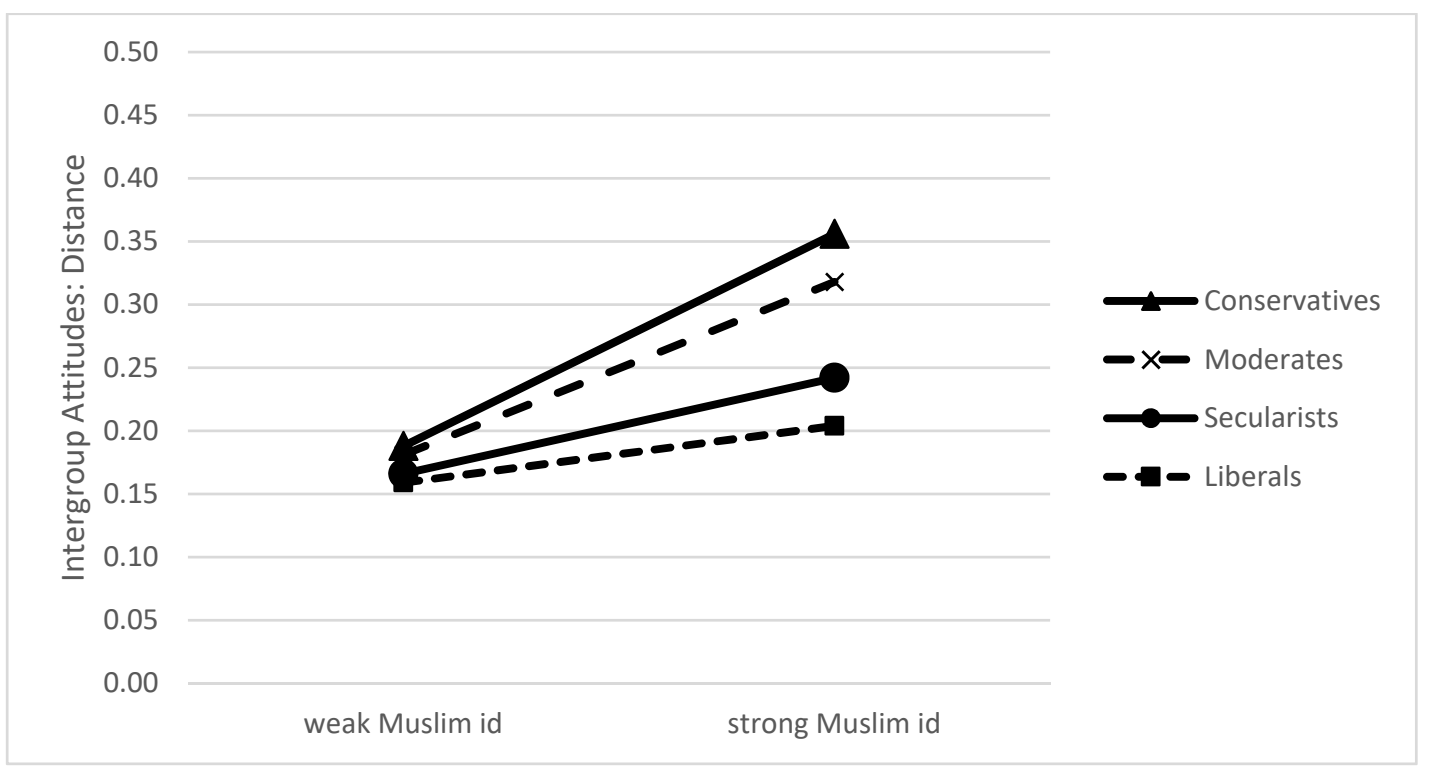

Figure 5. Supplementary Material. The interaction between Muslim identification and linear trend on Distance

Note. The intercept based on the distance towards ethnic minorities was used, as the latent intercept was not calculated 